\title{
The Poetry of Darwish in the 1960s: Homeland and Exile
}

\author{
Hajar Mahfoodh \\ College of Arts, University of Surrey, UK \\ $\&$ \\ ELC, University of Bahrain, Bahrain \\ Email: Hakadhem@uob.edu.bh; h.mahfoodh@surrey.ac.uk
}

Received: 6/24/2021 Accepted: 8/2/2021 Published: 8/25/2021

\begin{abstract}
The early poetry of Mahmoud Darwish (1941-2008) is characterised by its overt resistance and confrontational tone against the Israeli forces. This research paper explores the themes of homeland and exile in Darwish's poetry during the 1960s, tracing how the 1967 defeat has changed his poetic tone from the highly confrontational to the articulate conversational. It, therefore, contributes to the fields of literary criticism and Arab literary studies focusing on modern poetry of resistance. Although Darwish was still living on Palestinian lands during this period, he never felt at home, expressing his feelings of strangeness and suffering in a usurped land by force. The theoretical framework of Edward Said (1935-2003) is employed in this paper to question whether the themes of exile and homeland shape and reshape the Darwish's understanding of resistance. Based on the analyses of this paper, Darwish's poetry of resistance has dramatically changed due to his severe disappointment by the 1967 defeat, marking the collapse of Arab nationalism and its propaganda of the Arab homeland. Still, this shift does not affect Darwish's rejection of the Israeli existence in Palestine. Instead, his poetry by the end of this decade still questions the violent and aggressive nature of the Israeli soldier despite Darwish's intimate and human conversational style of his poems, thereby adding to the controversial analyses of Darwish's poetics.

Keywords: exile, homeland, Mahmoud Darwish, modern Arab poetry, Palestinian Studies, Postcolonial literature

Cite as: Mahfoodh, H. (2021). The Poetry of Darwish in the 1960s: Homeland and Exile. Arab World English Journal for Translation \& Literary Studies 5 (3) .

DOI: http://dx.doi.org/10.24093/awejtls/vol5no3.6
\end{abstract}




\section{Introduction}

The early poetry of Darwish is marked by a confrontational and militant stance, which Alshaer (2016) characterises as violent and emotionally intense, and it concentrated on reclaiming the homeland. In the 1960s, Darwish embodies the role of the activist who vows to liberate Palestine through direct combat to restore a usurped land. In his poetry, he associates homeland with geographic places and roots, and he defines his poetics of belonging as a form of nationalism that excludes the "other," namely the Israeli. On the other hand, Darwish's later poems are characterised by Sufism, in which he uses the textual world of the poem to express resistance and articulate the themes of homeland and belonging. Instead of the earlier angry tone and fierce combativeness, the poetry of Darwish re-articulates his poetics of resistance as a refusal of violence and hatred. In other words, Darwish articulates his exploration of alternatives and the option to reconstruct a liberated homeland with no boundaries between the Israeli and the Palestinian, leading the poet to question the deficiencies of the nation-state and national belonging.

This paper also analyses the poet's experience of deprivation and dislocation in exile. Darwish's exploration of the homeland in this decade presents the homeland as a victim of the PalestinianIsraeli conflict, which he interprets as a war of memories in which the combatants seek to exclude each other. Because national memory is at stake, the poetry of Darwish embodies his insistence on the poem to preserve memory when he says, "so I wrote: Who writes his story inherits/ The land of words and owns meaning totally!" (Darwish, 2012, p. 57). Khairallah (2011) indicates that for Darwish, the poem is the mighty dynamics that can preserve national memory by intersecting the collective and personal memories. In this sense, the poem is turned into a national narrative that safeguards the memory of the homeland, where the text becomes a poetic place for Darwish to create poetics of resistance.

This poetic shift from confrontation in his early poetry to negotiation and reconciliation reflects the poet's despair over the effectiveness and results of conflict and direct combat. According to Athamneh (2017), Darwish explores the Israeli not as an enemy but as an "other," suggesting that Darwish does not seek to exclude the Israeli in his late poetry. In this sense, Darwish exiles himself from his "Palestinian-ness" to explore the Other, through which he constructs a relationship based on mutual understanding and respect so that both can engage in a productive conversation to create a homeland. Through this metaphoric exile, Darwish initiates a poetic negotiation that explores the potential for a mutual understanding of the conflict, which has a long history in which the opponents dehumanize and attempt to erase each other's identity. Before exploring the poetry of Darwish, I will first briefly examine the historical background of his life.

\section{Literature Review and Background}

The homeland experience of Mahmoud Darwish (1941-2008) is of hostilities and suffering since he comes from Palestine, a country that has witnessed violent upheavals and fierce wars since the twenties of the last century. In 1917, the Balfour Declaration, a public statement by the British, announced the promise of a national state for the Jews on Palestinian lands while Palestine was still under the direct rule of the Ottoman Empire. This British declaration marks the beginning of an open-ended era of instability that has continued to the present day. Palestine was an Arab state under direct British mandate from 1923-1948, and, according to Khalidi (2007), during this 
period, colonial politics and forced rule severely suppressed and crushed several Palestinian uprisings, weakening Palestinian political leaders. The Peel Report (1937) introduced the plan of dividing Palestine into areas for Israel and areas for the Palestinians, which exacerbated intense upheavals and uprisings. Makhoul (2020) states that hostile clashes erupted between Palestinians and Israelis after the Partition Plan was adopted at the United Nations in 1947 and reached their peak in the Nakba (Arabic word for this Palestinian catastrophe) of 1948, uprooting more than 250,000 Palestinians. The United Nations, in 1948, officially authorized the partition of the two states, Israel and Palestine. However, this event marked only the beginning of an open-ended phase of increasingly permanent Israeli settlements and incursions on Palestinian territories that resulted in uprooting more Palestinians. These settlements include the 1967 Naksa, or "defeat," when Israel seized the Palestinian territories of the West Bank, East Jerusalem, Gaza Strip, Syria's Golan Heights, and the Egyptian Sinai Peninsula. After the violent uprisings, or Intifadas, both states signed a peace agreement in the Oslo Accords in 1993 (Khairallah, 2011). Still, this agreement has not succeeded in stabilizing either state. Instead, the Palestinian lands continue to decrease while Israeli settlements continue to expand steadily, and the uprisings have not stopped. These conditions have led both parties to suffer from insecurity and instability, creating a political crisis that has reached no firm resolution.

When exploring Darwish, it is significant to understand the complexity of the Palestinian situation in which the nation-state and, therefore, its people are perpetually subject to erasure and exile. The Palestinian refugee has lost both citizenship and identity during an era in which the Palestinian lands constantly and indefinitely shrink. Since the early days of their presence in Palestine, Israeli state politics have pursued a policy of erasing Palestine politically, socially, and even physically from the world map. Williams and Ball (2014) discuss this process of erasure, which has involved continuous encroachments and illegal settlements that have fragmented the Palestinian lands, as eventually creating on a physical level a "nowhere" Palestine. This dwindling of land is exacerbated by the Separation Wall that puts the remains of the Palestinian West Bank and Gaza under siege and the ongoing annexations of the Palestinian lands to the Israeli state. Israeli colonisation has turned Palestine into a state that used to exist with people who used to be Palestinians, but that is currently a state in which there is neither a place nor people. "Return" to their country is impossible for the many Palestinians scattered as refugees and wanderers overseas.

Not only did the uprooting of the Palestinians result in mass exile, but it also introduced dialectics that misrepresent and distort the Palestinian crisis in colonial and postcolonial literature. Bernard (2018) argues that the Palestinian-Israeli struggle is often circumscribed to boringness by a deliberate language, which has resulted in discrediting the Palestinian struggle; as she states, "it would be hard to find a more explicit use of the language of boredom as a means of invalidation" (p. 27). In addition, some scholars distort Zionism by ignoring it as a form of colonization, such as Sternhell (2010) who, when discussing the anti-Zionism movement, writes, "a quarter of a century ago, this idea had a certain novelty (...), but since then the anti-Zionists have established their own conformism and become stuck in its mire" (p. 99). Sternhell suggests that anti-Zionism is merely an outdated academic trend whose supporters and intellectuals have failed to change and develop rather than a form of ongoing colonialism. By presenting anti-Zionism as an intellectual trend that has expired, such literature not only labels the Palestinian struggle by association as 
static and outmoded, but it also normalizes the Palestinian struggle as over, and thereby makes their struggle to maintain identity futile.

After 1948, Palestinian poetry became more engaged with the Palestinian struggle with the newly established state of Israel. The Palestinian poet was part of the larger socially and politically destabilized homeland, where native Palestinians were subject to dislocation, imprisonment, and even death by identity. These unsettled conditions shaped how poetry expressed the Palestinian struggle, making it confrontational and violent at the beginning of the struggle. Since much poetry was produced in this context, Palestinian literature tends to be circumscribed and restricted to political jargon, which led to a misrepresentation of the literature, ignoring its aesthetics. Still, Palestinian poetry is political since it is born of resistance and a desire for freedom. The modern Palestinian poet is entwined in a poetic conflict between being part of modern poetry and the national struggle. Alshaer (2016) argues that for Darwish, "modernity clashed with the collective fate of his people" (p. 146). In other words, Darwish was torn between the poetry of commitment to the Palestinian cause, or Iltizam, and his poetic experimentation and development. While some Palestinian poets, like Tawfiq Zayyad, have remained dedicated to the poetry of political revolution and the fight against Israel, the poetry of Darwish has changed its embodiment of resistance as he moved from the experience of being within the homeland to becoming an exile.

Said (2013) states that Palestine as a homeland is a "site of an ongoing conflict for control" (p. 26), which he associates with mourning but also dispossession and exile. According to Said, this conflict is embedded and irreconcilable because ownership of Palestine is a Biblical right for the Israelis. This discussion is one of the aspects that can be found in the poetry of Darwish, where the homeland is an experience of a multifaceted conflict. The physical conflict is geographical, and the struggle is about reclaiming the loss of lands, while the metaphysical conflict is more complicated because it is a struggle between two historical memories and identities, which are in constant conflict in an attempt to erase each other. Since each party claims the right to claim the land, but not share, reconciliation seems impossible. In other words, this conflict is an existential one for Darwish, making his poetry of the homeland a matter of life and death.

\section{The Poetry of Darwish: Discussion and Analysis}

The atrocities of the homeland as experienced by Darwish accompanied him since the beginning of his life. His catastrophic experience of displacement is both personal and collective since he has experienced exile at a very early stage. Salam and Mahfouz (2020) record that the 1948 exiled Palestinians suffered from the traumatic experience that has accompanied them since then, leading to feelings of bitter suffering from the nostalgia of returning home. Darwish is one of these Palestinians who, as early as six years old, found himself in exile when the Israeli forced the villagers of Birweh, his hometown, to leave their homes. Darwish records how he had to flee for his life under the roar of the bullets, recalling how this night of forced flight ended his childhood. According to Akash and Forche (2013), the homeland experience of Darwish as one of hostility and violence began from that moment, and it continued even when he returned to his homeland and was legally labelled as a "present-absent alien." During this time, he was subject to severe restrictions that legally denied him the right to move from one village to another when he wanted to recite his poetry of revolt and resistance. Athamneh (2017) records that Darwish was 
affiliated with the Israeli Communist Party, and he worked as a literary journalist for their official newspaper. Because he often attempted to travel without permission from Israel, he was imprisoned several times until he left for self-imposed exile in 1971. His personal history significantly impacted shaping the homeland as an experience of violence, conflict, and constant resistance for Darwish.

In Identity Card, Darwish identifies himself as a kind of prisoner whose family is impoverished under the colonizing state of Israel although he is living in his homeland. Still, he insists that the Arab connection to the land is an ancient one, reaching back before time and the beginning of the agriculture that defines the land. He says,

My roots

Were entrenched before the existence of time,

Preceding the beginning of the ages,

And, before cypress and olive

(Darwish, 1993, p.48).

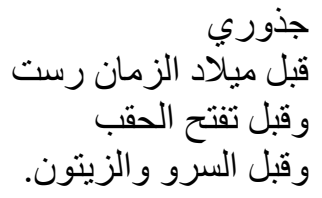

The poem is confrontational throughout, since he directly addresses and questions a "you" as an Other when he says, "Does that anger you?/ فهل تغضب." To any listener, but especially to the Palestinian listener, the implication is that he is speaking to the Israeli state, the "usurper" that has imprisoned him and taken away his land, leaving him only rocks. The peak of inciting violence appears at the end of the poem by recognizing not only shared anger but by taking a threatening stance when he says,

I do not hate people

Or raid anyone

Still, when hungry

I devour my usurper's flesh

Beware... Beware... Of my hunger

And, of my anger (Darwish, 1993, p 50).

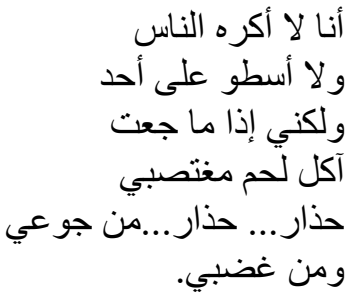

Darwish's actions, as he explains, are not born out of random aggression but out of necessity and the need to survive. By saying so, Darwish suggests that confrontation is the only way to survive and live in this usurped homeland. Darwish's approach is in line with Said (1984), who argues that Palestinian nationalism is "derived from the great wave of Arab and Islamic anti-colonial sentiment (...) and located within the mainstream of secular post-imperialism" (p. 32). Since Palestinian nationalism is anti-colonial, it is logically in confrontation with that of the Israeli as a form of colonization.

This poem represents most of the poetry before Darwish's exile, where he presents the colonised homeland as possibly restorable when liberated from colonisation. In other words, Darwish presents the homeland as a physical place that could be reclaimed once the colonizers are dismissed. By dismissing the colonizer, Darwish claims the homeland as an exclusive right for the natives, the Palestinians, while he shows no hospitability or understanding of the possibility of 
coexistence with the Israelis. Instead, the Israeli is presented as an enemy "other" who has no right to live in Palestine.

Darwish reconstructs a textual homeland as a form of resistance to Israel's colonial attempts to erase the Arabness of Palestine by insisting on preserving "Arabness" in terms of language and identity. Mukattash (2016) maintains that Darwish seeks to restore the homeland by restoring language because "by restoring the Arabic language, Darwish is restoring the lost land and the lost identity" (p. 20). Mukattash further implies that language denotes home(land) and identity in the poetry of Darwish on a personal level, where the poem is a means of reclaiming the poet's loss. The loss in this sense is that of belonging, which takes different forms: the physical, including land and property, and the metaphorical, such as memory and language. Building on Mukattash, the researcher contends that Darwish's restoration of the Arab language is a form of reconstructing national memory, reaching beyond land and personal identity. To retain belonging, Darwish uses his poems to construct a personal memory that can reassemble the collective memory of the Palestinians. Darwish states that his poetry has accepted the responsibility of documenting the Arab memory "to prevent those who colonized the land from colonizing memory" (as qtd in Abu Eid, 2016, p. 60). In other words, Darwish uses the textual homeland to preserve Arab memory and identity from colonial distortion. Hence, the textual homeland embeds the chronicles of the Arab national memory as a form of resistance to the Israeli attempts to erase the "Arabness" of Palestine and Palestinians.

Because Darwish insists on belonging to the homeland, his early poetry reconstructs the Palestinian suffering into a hope for a better future by insisting on the inevitable end of Israeli colonization. Instead of surrendering to the colonizer, Darwish insists on an imagined and inevitable end of the Israeli occupation. In About a Human Being from the same collection, Darwish creates hope for the Palestinians under Israeli custody despite the Israeli tyranny and brutality when he says,

You, whose arms, and palms are bleeding, night is impermanent

the detention room and the harsh chains will not stay

Nero died, but Rome remained

fighting with its eyes (Darwish, 1993, 16).

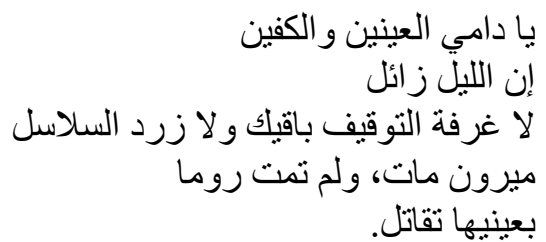

بعينيها تقاتل.

Here, Darwish creates hope for the suffering of Palestinians, especially those under custody, by drawing an analogy to the end of the infamous Nero of Rome. This trend of turning the defeat into hope is more apparent in the poetry written after the 1967 Naksa, when many Palestinian poets, such as Darwish, Samih Al-Qassim, and Tawfiq Zayyad, insisted on creating hope of a homeland without Israel. According to Athamneh (2017), "placing utmost faith in the persecuted Palestinian Arab (...) and promising victory over the State of Israel, Darwish's poetry evoked feelings of pride and steadfastness among Palestinians and Arabs after the 1967 defeat" (p. 202). In other words, Darwish turned the defeat into a cause of hope for a better future for the Palestinians by expressing more resistance to Israel. At the same time, and by insisting on reclaiming the homeland, Darwish

Arab World English Journal for Translation \& Literary Studies 
articulates the homeland as exclusive to the native people and cannot be shared with the Israeli people.

However, Darwish's attachment to roots and land and his insistence on nationalism changed in his poetry after the 1967 Naksa since it comprised a defeat of Arab nationalism, a myth that failed to secure the Arab people and the Arab homeland. Despite his refusal to accept defeat, Darwish's poetry underwent a significant change that would crystalize further in his poetic life in exile. In this later poetry, he explores the porous boundaries of nationalism and the nation, which leads him to engage in conversations with the Israeli, decreasing the distance he created in his writing. Still, he insisted on making exact the boundaries defining Israeli and Palestinian national identities, and which this paper explores in his controversial poem A Soldier Dreaming of White Tulips from his collection Late Night, first released in 1967.

In this collection, the poetic tone of Darwish is far from being confrontational, although he still insists on dehumanizing the Israeli as a colonial and imperial power. He also presents the homeland as an experience of alienation, death, and hostility rather than a feature crucial to identity and security. The homeland's hostilities deprive Darwish of his love in his poem, Rita and the Rifle, where he articulates his personal love story with Rita, an Israeli woman. Despite its sincerity, Darwish (2005) is aware that their love is very difficult to sustain because it is haunted by the rifles of Israeli soldiers shooting Palestinians, "between Rita and my eyes, lies a rifle" (بين ريتا وعيونسي (بندقية) (p. 202). While exploring the homeland's hostilities, Darwish is triggered to address new questions, such as the basis of Palestinian belonging and whether the homeland as a nation that provides a satisfactory source of identity and security is a myth.

As the title indicates, A Soldier Dreaming of White Tulips indicates a world of dichotomies where the soldier's military image contrasts with the white flowers' beauty and purity. Using the free verse, Darwish engages in a dialogue with an Israeli soldier to explore the Israeli's psychology, and Israel itself is symbolized by a soldier whose career is to kill people in wars. Still, Alshaer (2016) states that Darwish acknowledges the human part of the Israeli in this poem, as the soldier "reveals to Darwish his thoughts and emotions, recorded in the poem with resigned neutrality and sympathy" (154). The soldier confesses in the poem (Darwish, 2005):

(...) and soldiers,

Sin when they are sad,

I was there, a machine spreading fire and death (p. 208).

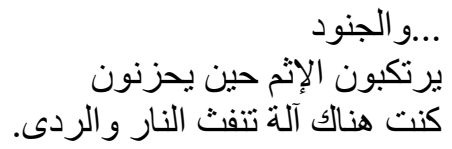

The soldier who has found a voice in this poem is a human being who has feelings and love, but as human in nature, he errs as well.

According to Athamneh (2017), Darwish was accused of normalizing the Israeli occupation by Arab nationalists, critics, and politicians because of this new and less condemning attitude. On his part, Darwish acknowledges that his colleagues did not well receive the poem at the Communist Party, and they wondered whether he was requesting the Israelis to leave as a condition to 
becoming peace-makers (Shatz, 2006). Based on Darwish, the researcher would argue that the poem stands as a revolt that resists conforming to either national narrative and marks Darwish's early exploration of the Israeli's human side, whether and how it exists. What I want to say is that Darwish wanted to escape what Barghouti (2003) terms as "two pressures: one from [his] audiences pressing for clear and direct handling of the collective themes and preoccupations, and another from within, pressing for the singular, the personal and the genuinely private" (p. 146). Barghouti indicates that the poet was subject to a conflict between his national commitment and his poetic desires and aspirations as a modern poet who seeks poetic experimentation and change. Hence, this poem marks Darwish's poetic divergence from the confrontational to the conversational poem that articulates resistance through logic and philosophy rather than protests and rallying.

By initiating a relationship of equity between the Israeli soldier and the poet, the poem defies confining the Israeli-Palestinian relationship only to conflict and its clashing nature. Darwish (2005) begins the poem with,

He dreams of white tulips, of an olive branch, of the blossoms of lemon (p. 203).

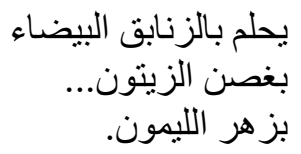

Darwish describes the dream of an Israeli soldier dreaming of peace, symbolized by the olive branch. Mattawa (2014)argues that Darwish describes the soldier with positive images that remind us of Darwish's early poetry, in which he uses lines such as "I long for my mother's coffee" to portray his friendship with the Israeli soldier. Darwish also associates the soldier with lemon blossoms, a symbol often associated with the native of Palestinian Darwish's poetry. In one way or another, Darwish presents the Israeli soldier as a human being who can communicate and converse, which is much different from the image of the Israeli that he presented in earlier poems, such as Identity Card.

However, the poem is still created by contrasting Palestinian identity with the Israeli, as pointed out by Athamneh (2017), who argues that the poem "highlights the Palestinian identity by contrasting it with that of the Israeli other" (p. 210). To reveal these contrasts, Darwish asks the soldier several questions to show the difference between the Palestinian and Israeli narratives. When the speaker of the poem asks the soldier what he knows about his land, he simply replies, "I do not know it, he said/ nor do I feel it in my flesh and blood" (قال: لا أعرفها/ و لا أحس أنها جلدي ونبضي) (Darwish, 2005, p. 204). By denying an attachment to the land, the Israeli soldier is also confessing that he does not belong to this homeland, Palestine. Darwish insists that the Israeli soldier does not belong to Palestine, and hence, the homeland for Darwish belongs exclusively to its native people.

The speaker asks short questions, but they continue to convey his attachment to the homeland, such as when he asks the soldier, "Would you die for the homeland?" By asking this, he suggests that he, the speaker, would die for his homeland, whereas the Israeli soldier might not. Another contrast lies in the Palestinian speaker who states, "I asked him, torturing myself/ describe one murdered person” (سألته، معذبا نفسي، إذن/ صف لي قتنيلا واحدا) (Darwish, 2005, p. 206). By doing so, 
Darwish shows the extent of the speaker's compassion: just to ask such a question causes his deep pain, whereas the brutality of the soldier is revealed in his answer, "I exploded red tulips in the sand...in bosoms... and bellies" (فجرتها في الرمل... في الصدور... في البطون) (Darwish, 2005, p. 206). For the soldier, there is no difference between the blood of his targets and red flowers. Darwish exposes the Israeli as a soldier hunting for the sensual and corporeal through such contrasts, which cannot establish belonging, according to Darwish. Mattawa (2014) maintains that the Israeli's sense of belonging is based on "excavating non-living, human-made things" while the Palestinian is attached to the homeland as "a living creature" (p. 61). In other words, Mattawa indicates that the Israeli's sense of belonging is attached to the mortal, and the homeland is dead or irrelevant, while the Palestinian belonging is alive because it belongs to the earth, which is the seat of all living things. Here, Darwish is accusing the Israeli of forging a sense of belonging through the manmade, which contrasts their national narrative of a divine-given homeland. This image is contrasted by the Palestinian sense of belonging, rooted in land, culture, and ancestry. By doing so, Darwish insists on denying the Israelis the right to belong to his homeland.

In comparison, the experience of exile has a different impact on Darwish; exile liberates the poetry of Darwish from the constraints of national commitment. Exile for Darwish as a means of liberation resonates with Said's Out of Place. Said (2012) believes that despite the bitterness and trauma of exile, it is through exile that he has become independent and liberated in his thought. For Darwish, confrontational poetry that calls for resistance was an existential issue that concerned him when he lived in his occupied homeland, but it was also part of his socio-political commitment to nationalism and his homeland. However, the rupture of exile liberated him from his national obligation and allowed him to explore the idea of his colonised homeland differently. Before exile, Darwish sustained the rhetoric of "either Israel or Palestine"; after the exile, he began to address how and why Israel and Palestine could coexist. In his later poems, Darwish explores the Israeli, not as the enemy "other," but as the "other," who is also a victim of violence and conflict. Darwish's poetic journey transports him from violence to peace, exclusion to inclusion, and denial of the other to acknowledgment and mutual respect.

The exile experience has also liberated the poetic revolt and non-conformity of Darwish, who reassembles a textual homeland defined by resistance, freedom, and exile. Cocks (2009) argues that in Said's portrait of a rebel, the "most ebullient moment" is "when the exile becomes a rebel who challenges conventions, destabilizes society, and evades the corruptions of power and perversions of gods that fail" (p. 154). Cocks suggests that the rupture of exile liberates the poet's writing from different constraints since it provides the exile with a free space to express criticism against his own culture and homeland. One of the conventions that Darwish resisted is the notion of the geographic state defined by borders. Mukattash (2016) implies that the poetry of Darwish reconstructs identity that goes beyond the geographic borders through the textual portrayal of homeland and belonging. In this sense, Darwish is similar to Al-Bayyati, who reconstructs a liberated, textual homeland, as discussed in the previous chapter. However, the textual homeland of Darwish is a place of mutual respect and understanding between the poet and the "other." This reconstructed homeland defies the nationalist perspective Darwish used before his exile, where he denied the Israeli the right to even exist in his homeland. By presenting the enemy as an equal

Arab World English Journal for Translation \& Literary Studies 
partner in the suffering caused by conflict, Darwish resists the colonial concept of this conflict as a war of excluding and erasing identities.

Darwish's experience of exile allows him to explore the fragmented identity of the Palestinian. Said (1999) states that "Palestinian life is scattered, discontinuous, marked by the artificial and imposed arrangements of interrupted or confined space, by the dislocations and unsynchronised rhythms of disturbed time" (p. 20). In other words, Israeli interventions, such as the loss of land, massive exile, and other forms of deprivation, have caused existential alterations in the Palestinian's lives. Because of these conditions, Palestinians have lost the means of security and stability that a homeland provides and are often prone to unpredictable homelessness; consequently, the Palestinian identity has become fragile and fragmented. In the early poetry of Darwish, fragmentation and homelessness are presented as incomplete and unfinished things that are put together to reassemble the Palestinian identity. Commenting on "A Lover from Palestine," Said (2013) says,

[T]this need to reassemble an identity out of the refractions and discontinuities of exile is found in the earlier poems of Mahmoud Darwish [.] He depicts his sense of homelessness in the form of a list of unfinished and incomplete things (p. 185).

Building on Said, I would argue that Darwish collects the fragmented "selves" of the poet to reconstruct a Palestinian who is both individual and collective. This use of the fragmented to build the collective is a significant characteristic of Darwish, whose poetry portrays a spontaneous transport between the poet's different "selves" and the fragmented and the collective "selves." By this movement between the fragmented and the collective, Darwish metaphorically expresses resistance to belonging to either. Instead, they contribute to shaping each other and presenting the Palestinian identity as dynamic, alive, and constantly changing.

To accommodate the fragmented and collective identities addressed in the same poem, Darwish adopts Sufism as a means of hybrid transport. I use the term hybrid transport to refer to shifting that involves free traveling, horizontally and vertically, in time and space, where space and time form the axes of a poetic graph. Darwish travels horizontally in space because his poem is unloosed from geographic borders and traditional cartographies, but he also travels vertically because his poetry moves beyond the limits of time. Within the poem, Darwish shifts freely from past to present, or vice versa, and his sense of time is not necessarily linear. Instead, he adopts the characteristics of Sufi poetry, which provides this freedom of hybrid mobility. In Sufism, time is imaginary but also subjective; as Adunis (2013) explains, "time is what you are in" (p. 125), implying that the Sufi poet controls time, enabling the poet to move without physical or metaphysical constraints because Sufism creates an absolute alienation and disconnection with this world.

Further, Darwish's poetry embeds another Sufi transport where he moves in and out of his "self," according to Bernard and El-Marsafi (2012). In other words, Darwish moves through

Arab World English Journal for Translation \& Literary Studies 
multiple "selves," where sometimes one "self" is estranged from another, such as when he says in Two Strangers (2009):

He looks in the mirror

And sees a stranger like him

Looking at him! (p. 24).

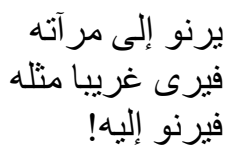

فيرنو إليها

Hence, the Sufi poem is a means of creating a hybrid of transport and absolute freedom that allows Darwish to transport in imaginary and non-finite directions and destinations through time and space.

\section{Conclusion}

This paper has explored Darwish's homeland experience while living in the occupied part of Palestine in the 1960s. During this period, his poetry presents the homeland experience as one of hostilities and insecurity through his depiction of Israeli officers' cells and torture. Still, he insists on belonging to the national homeland, which he reconstructs through his national and collective Palestinian narrative. In addition, the homeland is a physical place and presented as a usurped land that could be reclaimed once the colonizers are dismissed. By dismissing the colonizers, Darwish claims the homeland as an exclusive right for the Palestinians, while he shows no hospitability for the Israeli or understanding the possibility of coexistence. Instead, the Israeli is presented as an enemy who has no right to live in Palestine. Still, after the 1967 defeat, Darwish abandons his confrontational poetry of protest and opts for a conversational style. Although Darwish uses his poetry to explore the Israeli psyche, it exposes the Israeli's inhumanity and brutality as an enemy who has no right to belong to this land.

\section{About the Author:}

Hajar Mahfoodh is currently pursuing her Ph.D. in Literature at the University of Surrey, the United Kingdom, working on exile and home in modern Arab poetry. She is also employed as an English lecturer at the University of Bahrain. Hajar is interested in modern literature, creative writing, and postcolonial theory, and she has published some of her experimental poetry. ORCID ID: https://orcid.org/0000-0001-7408-8015

\section{References}

Eid, M. A. (2016). Mahmoud Darwish: literature and the politics of Palestinian identity. Bloomsbury Publishing.

Adonis, A. (2013). Sufism and surrealism. London: Saqi.

Akash, M., \& Forche, C. (2013). Introduction. In M. Darwish, (eds), Unfortunately, it was Paradise: Selected Poems (pp. xv-xix ). California: University of California Press.

Alshaer, A. (2016). Poetry and Politics in the Modern Arab world. C Hurst \& Co Publishers Ltd.

Athamneh, W. (2017). Modern Arabic Poetry. USA: University of Notre Dame Press. 
AWEJ for Translation \& Literary Studies Volume, 5 Number 3. August 2021

The Poetry of Darwish in the 1960s: Homeland and Exile

Mahfoodh

Barghouti, M. (2003). I Saw Ramallah. (A. Soueif, trans) A. New York: Random House.

Bernard, A., \& Elmarsafy, Z. (2012), Intimacies: In Memoriam Mahmoud Darwish. Interventions, 14(1), 1-12.

Bernard, A. (2018). Rhetorics of Belonging: Nation, Narration, and Israel/Palestine. Liverpool: Liverpool University Press.

Cocks, J. (2009). Passion and Paradox: Intellectuals Confront the National Question. $\quad$ USA:

Princeton University Press.

Darwish, M (1993). Olive Leaves. Dar Al- Awda.

Darwish, M. (2005). Al-Diwan (1). Riad Al-Rayyes Books.

Darwish, M. (2009). A river dies of thirst (C. Cobham, trans). USA: Archipelago.

Darwish, M. (2012). Why did you leave the horse alone?. Archipelago.

Eid, M. A. (2016). Mahmoud Darwish: literature and the politics of Palestinian identity. Bloomsbury Publishing.

Khairallah, A. (2011). Mahmoud Darwish: Writing Self and History as Poem. In R. Baalbaki, S. Agha, \& T. Khalidi (eds.) The Value of Poetry in Reconstructing Arab History (pp. 335360) Lebanon: American University in Beirut Press.

Khalidi, R. (2007). The iron cage: The story of the Palestinian struggle for statehood. London: Beacon Press.

Makhoul, M. M. H. (2020). Palestinian Citizens in Israel: A History Through Fiction, 19482010. Edinburgh: Edinburgh University Press.

Mukattash, E. K. (2016), The Politics of Identity in Mahmoud Darwish's Absent Presence: A Textual Act of Resistance. Studies in Literature and Language, 12(2), 17-27.

Mattawa, K. (2014). Mahmoud Darwish: The Poet's Art and His Nation. New York: Syracuse University Press.

Peel, W. R. W. P. (1937). Palestine royal commission report.

Said, E. W. (1984), Permission to Narrate. Journal of Palestine Studies 13(3), 27-48.

Said, E. W. (1999). After the last sky: Palestinian lives. Columbia University Press.

Said, E. W. (2012). Out of place: A memoir. Vintage.

Said, E. W. (2013). Reflections on exile: and other literary and cultural essays. Granta Books.

Salam, W. J., \& Mahfouz, S. M. (2020). Claims of memory: Transgenerational traumas, fluid identities, and resistance in Hala Alyan's Salt Houses. Journal of Postcolonial Writing, 56(3), 296-309.

Shatz, A (2006). A Love Story between an Arab Poet and His Land. In J. Beinin, \& R. Stein (eds.) The struggle for sovereignty: Palestine and Israel, 1993-2005 (219-229). California: Stanford University Press.

Sternhell, Z. (2010), Defence of Liberal Zionism. New Left Review, 62, 99-114.

Williams, P., \& Ball, A. (2014), Where is Palestine?. Journal of Postcolonial Writing, 50(2), 27-133.

Arab World English Journal for Translation \& Literary Studies

ISSN: 2550-1542 | www.awej-tls.org 